Original Paper http://ajol.info/index.php/ijbes http://indexmedicus.afro.who.int

\title{
Knowledge and attitude of youths to substance abuse in Alimosho Local Government area of Lagos State
}

\author{
Gloria Oiyahumen ANETOR ${ }^{{ }^{*}}$ and Mary Funmilola OYEKAN-THOMAS ${ }^{2}$
}

\author{
${ }^{1}$ National Open University of Nigeria (NOUN), 91, Cadastral Zone, University Village, Nnamdi Azikiwe \\ Express Way, Jabi, Abuja, Nigeria. \\ ${ }^{2}$ Neuro - Psychiatric Hospital, Yaba Lagos, Nigeria. \\ * Corresponding author; E-mail: yahuanet@yahoo.com
}

\begin{abstract}
Substance abuse is a huge global health and critical problem which has made it a matter of significant public health importance in most countries. Substance abuse poses a significant threat to the health, social and economic fabric of families, communities and nations. This study examined the level of knowledge and attitude of youths to substance abuse in Alimosho Local Government; the most populous Local Government Area in Lagos State. The study was aimed at exploring the general knowledge of substance abuse among youths; examining the relationship between youths' knowledge of substance abuse and substance use; exploring their attitude to substance abuse and proffer possible strategies that can be employed to address substance abuse among youths in order to ameliorate the growing problem substance abuse in youth population. A cross-sectional study design was employed to select youths within the age range of $18-35$ years for the study. A sample size of 350 was selected and 340 analysable questionnaires were returned (attrition rate of 3\%). Self-structured validated questionnaire was administered. The questionnaire was divided into three sections: Socio-demographics of the participants, Knowledge on drug abuse, attitudes and perception towards drug abuse. The statistical analyses of frequency counts, percentages and Pearson's Chi square using the Statistical Package of Data Analysis (SPSS) 2012 to test the hypotheses at 0.05 significance level. Findings showed adequate knowledge of the risks of substance abuse among youths and there was indifference in the attitude of youths to the use of drugs. In conclusion, the negative attitude of youths to substance abuse is a cause for concern since the youths are the future of the nation. It was recommended that health education intervention, stressing the health implications of substance abuse and how to come off substance abuse through psychotherapy should be put in place.
\end{abstract}

(C) 2018 International Formulae Group. All rights reserved.

Keywords: Psychoactive drugs, psychiatric hospital, health education, adolescents and young adults.

\section{INTRODUCTION}

Substance abuse have many synonyms which include drug abuse, psychoactive substances abuse, illicit drugs use and are often used interchangeably. Substance abuse is also described as a patterned use of a drug in which the user consumes the substance in amounts or with methods which are harmful to themselves or others, and is a form of substance-related disorder (American Psychiatric Association, 2013). In the same vein, the World Health Organization (2017) Lexicon of Alcohol and Drug Terms defines substance abuse as a "maladaptive pattern of 
use indicated by continued use despite knowledge of having a persistent or recurrent social, occupational, psychological or physical problem that is caused or exacerbated by the use (or by) recurrent use in situation in which it is physically hazardous."

Substance abuse is a huge global health and critical problems which has made it a matter of significant public health importance in most countries and it is associated with several social and economic consequences such as failure to meet work, family, or school obligations, interpersonal conflicts, legal problems, addiction and HIV/AIDS which are serious consequences. According to the Global Burden of Disease Study (2013), the use of psychoactive substances among adolescents and young people has become a subject of public health concern worldwide partly because of its potential to contribute to unintentional and intentional problems.

Substance abuse poses a significant threat to the health, social and economic fabric of families, communities and nations. The extent of worldwide psychoactive substance use is estimated at 2 billion alcohol users, 1.3 billion smokers and 185 million drug users (WHO, 2002). In an initial estimate of factors responsible for the global burden of disease, tobacco, alcohol and illicit drugs contributed together $12.4 \%$ of all deaths worldwide in the year 2000 (WHO, 2002).

Substance abuse is a universal phenomenon that cuts across socioeconomic, cultural, religious and ethnic boundaries and despite the efforts of the various tiers of government to stem its tide in Nigeria, there has been a consistent rapid rise in the number of cases especially among adolescents and youths who are 10-24 years. This has resulted in an increase in the number of cases of cultism, violent disorders, as well as mental disorders among Nigerian youths (Oshikoya, 2006). Globally, it is estimated that in 2010 between 153 million and 300 million people aged 15-64 (3.4-6.6 per cent of the world's population in that age group) had used an illicit substance at least once in the previous year (UNODC, 2012). According to the research article published by the United Nations in 2012, the extent of illicit drug use has thus remained stable, but the estimated 15.5 million-38.6 million problem drug users (almost 12 per cent of illicit drug users), including those with drug dependence and drug-use disorders, remain a particular concern. It is also estimated that there were between 99,000 and 253,000 deaths globally in 2010 as a result of illicit drug use, with drug-related deaths accounting for between 0.5 and 1.3 per cent of all-cause mortality among those aged 15-64 according to the United Nations Office on Drugs and Crime World Drug Report of 2012 (UNODC, 2012). Reports all over the world have shown increasing trends in substance abuse among teenagers, youths, commercial bus drivers and other categories of people and with the antecedent public health problems associated with the abuse of these substances (Cherpitel et al., 2003; Welcome and Pereverzev, 2010; UNODC, 2012).

In Nigeria, there seem to be an increasing prevalence of drug abuse amongst adolescents despite the efforts of concerned bodies to curb this menace. There has been a growing trend in the use of psychoactive substances. Empirical observations and media reports indicate that psychoactive substance use and misuse remain quite substantial (Suleiman et al., 2006). Other studies reported that in Nigeria, earlier studies on students' substance use were largely hospital-based and confined to selected regions of the country (Oshodi et al., 2010). However, in the past 1015 years, such studies have taken the form of field work employing epidemiology techniques so as to provide more comprehensive information related to types, pattern of use and psycho-social correlates in drug use among secondary school students (Fatoye and Morakinyo, 2002; Omalase et al., 2011). Also, Fareo (2012) reported that students, especially those in secondary school tend to see the drug user as one who is tough, bold and strong. Many youngsters have been known to use drugs at the instance of peers, elders or siblings. Students who usually feel inadequate have been known to use drugs to achieve social acceptance. He further reported that previous research work indicated that the problem of drug abuse know no boundaries or 
social class. It impedes the development of any society as it is a threat to life, health, dignity and prosperity of all individuals.

The Ministry of Health in Lagos State recently declared that particularly worrisome is the escalating use of alcohol and mindaltering drugs amongst youths in Lagos State. This habit is closely linked with juvenile delinquency, school failure, HIV/AIDS transmission, violent crimes and a generally unsafe environment. Use of heroin and cocaine is more prevalent in Lagos and other metropolitan cities (LMoH, 2017). Alcohol abuse and heroin could cause a spike in blood sugar: for example, heroin seems to interact with the pancreas, and the complex chain reactions heroin can cause could produce hyperglycemia. Apart from probable early development of type 2 diabetes, the female youth may start to have a heavy menstrual flow from hyperglycaemia (Sheldon and Quin, 2005; Vue and Setter, 2011; Omorogiuwa and Okolo, 2015). In the same vein, tobacco which is one of the most abused substances by youths has been reported to kill nearly 6 million smokers worldwide each year including more than 600,000 non-smokers who die from smoke exposure (Gashaw et al., 2016).

In light of the above situation, the current study was conceived to examine the level of knowledge and attitude of youths to substance abuse in Alimosho Local Government in Lagos State; the most populous Local Government Area in Lagos State, which is one of the most densely, populated states in the country. This was with the intention to examine the general knowledge of youths about drugs and their effects; explore their attitude to substance abuse and proffer possible remedies for lapses that may be found in order to ameliorate the growing problem of drug or substance abuse in youth population. To this end, the following hypotheses were tested:

1. Ho1: There will be no significant difference in the knowledge of substance abuse among youths in Alimosho Local government area of Lagos State.

2. Ho2: There will be no significant relationship between the knowledge of substance abuse and the way that the youths abuse substance in Alimosho Local government area of Lagos State.

3. Ho3: There is no significant relationship between attitude of youths toward Substance abuse and Prevalence of Drug/Substance abuse in Alimosho Local Government Area of Lagos State.

The study was aimed at: exploring the general knowledge of substance abuse among youths; examining the relationship between youths' knowledge of substance abuse and substance use; exploring the attitude of youths to substance abuse and proffer possible strategies that can be employed to address substance abuse among youths in order to ameliorate the growing problem substance abuse in youth population.

\section{MATERIALS AND METHODS}

\section{Study area}

This study was carried out in Alimosho Local Government Area (LGA) in Ikeja division of Lagos State of Nigeria. It is the largest local government in Lagos with over 1.3 million people living there according to the official 2006 Census. This study examined the level of knowledge and attitude of youths to substance abuse in Alimosho Local Government; the most populous Local Government Area in Lagos State and Lagos state happens to be one of the most densely populated states in the country. The Lagos State Government put the population within the LGA to over 2 million residents with the youths accounting for 700,000 to 900,000 (Lagos State Bureau of Statistics, 2013).

\section{Ethical approval}

Ethical approval was gotten from the Health Research and Ethics Committee (HREC) of the Federal Neuropsychiatry Hospital Yaba, Lagos to carry out his study. The participants signed informed consent form to participate in the study.

\section{Research design, sample and sampling technique}

A descriptive cross-sectional study whereby the inclusion of youths for the study was within the age range of $18-35$ years was 
designed. Calculated sample size was 344 but a sample size of 350 was selected for the study and 340 analyzable questionnaires were returned (attrition rate of 3\%). Multistage sampling was used to select the participants for this study. The first stage was the stratification of the local government by zoning of the LGA. There are forty (40) wards in Alimosho Local Government Area and the wards were divided into 4 zones: north, south, east and west with each zone comprising of 10 wards. The second phase was the selection of wards. Three (3) wards were selected from each zones using simple random sampling method by balloting. A total of 12 wards out of the 40 wards in Alimosho LGA were used for this study. The third stage was that of the selection of the participants for the study. Before selecting the participants, the aim of the study was fully explained to them and they were informed that they will sign a written consent to take part in the study and that if selected, taking part in the study was voluntary and they were free to decline. After the explanation, youths between the ages of 18- 35 years in each of the 12 selected wards were purposively selected and they were 700 in number. Using systematic random sampling of every $2^{\text {nd }}$ person, a total of 350 youths were finally selected for the study.

\section{Research instrument}

A self-structured questionnaire was the instrument used for data collection. The questionnaire was pretested and validated; the reliability coefficient was $\mathrm{r}=0.8$ using Cronbach Alpha. The questionnaire was divided into three sections:

a) Socio-demographics of the participants

b) Knowledge on drug abuse

c) Attitudes and perception towards drug abuse

The questionnaires were then administered by the lead researcher and 2 trained assistants.

\section{Data analysis}

The statistical analyses used include frequency counts, percentages, Pearson's chi square and relative risk ratio to measure association were used to test formulated hypotheses using the Statistical Package of Data Analysis (SPSS) 2012 version. The results were determined at a $95 \%$ confidence level at $\mathrm{p}<0.05$ significant level.

\section{RESULTS}

In Table 1, the gender shows that the female respondents were $38.8 \%$ of the total population, while male respondents $61.2 \%$ of the total population. For the age group of the participants, $11.8 \%$ of the participants were age $11-15$ years, $42.5 \%$ of the participants were between age 16 - 20 years while $34.4 \%$ of the participants were between ages 21-25 and $11.2 \%$ of the participants were ages 26 to 30 years. This shows that most of the participants were between $16-20$ years of age. The participants' marital status shows that $74 \%$ of the participants were single, $21.8 \%$ of them were married and $4.1 \%$ of them belonged to other groups. This implies that most of the study participants were single.

The analysis of the participants' ethnic group suggests that $48.8 \%$ belong to Yoruba ethnic group, 3.8\% belong to Hausa ethnic group, while $47.7 \%$ were of Igbo origin. This suggests that there were more of Yoruba and Igbo participants in the study. The analysis of the participants' family type shows that $28.82 \%$ were from monogamous family, while $57.65 \%$ were from polygamous family and $13.53 \%$ were from extended family. This suggests that more than half of the study participants were from polygamous homes.

Table 2 reveals that on the average, over $80 \%$ of the sample population (strongly agreed and agreed) demonstrated knowledge of drug/substance abuse in Alimosho Local Government while 3.52 percent were Neutral. However, $15.68 \%$ of the sampled population (disagreed and strongly disagreed) did not have adequate knowledge. This finding suggests a high index of knowledge of substance abuse among the youths. Chi square analysis in Table 3 further revealed the statistical significant of the knowledge of substance abuse among the youths. From the chi square in Table 3, the total number of observation is 340 . The value of Pearson Chi Square coefficient is $1595.645^{\text {a }}$ while the $\mathrm{P}$ value is 0.000 . Since the $\mathrm{P}$ value is less than 
the traditional benchmark value of 0.05 , it suggests that there is a significant difference. The Linear by Linear association ( $P$ value $=0.000$ ) also suggest that there is an association between the variables.

In Table 4, the questions sought to know whether there is relationship between the knowledge of substance abuse and the abuse of substance among the youths. Averagely, 69.66\% (strongly agreed and agreed) of the sampled population were in support of using drugs despite their apparent knowledge. Although, $10.68 \%$ of the sampled respondent were neutral; averagely, $16.94 \%$ (strongly disagreed and disagree) appear not to use drugs indiscriminately because of their apparent knowledge. Table 5 on the chisquare analysis further reveals this relationship; the total number of observation is 340. The value of Pearson Chi Square coefficient is $1567.353^{\mathrm{a}}$ while the $\mathrm{P}$ Value is 0.000 . The P. value $(0.000)$ is less than the traditional benchmark value of 0.05 ; it suggests that there is significant relationship. The Linear by Linear association (Pvalue $=0.000)$ and the likelihood ratio ( $\mathrm{p}$ value0.000 ) also suggest that there is an association between the variables.

Table 6 revealed the attitude of the youths to substance abuse. Averagely, over
$83 \%$ (strongly agreed and agreed) of the youths appear to be supportive of substance abuse. Meanwhile, 9.09 percent of the respondents were neutral and only $7.61 \%$ (strongly disagreed and disagreed) appear to have the right attitude and were not supportive of substance use. Table 7 shows the chi square analysis of the attitude of the youths to substance abuse. The result shows a total number of observation of 340 respondents, Pearson coefficient $(\mathrm{r}=809.339 \mathrm{a}, \mathrm{p}=0.000)$, Likelihood ratio (592.046, $\mathrm{p}=0.584$ ) while the linear by linear association $(15.539, \mathrm{p}=0.000)$. The probability value $(\mathrm{P}=0,000)$ is less than the 0.05 benchmark suggesting a significant association between the variables.

Figure 1 shows that Muslims were $56.2 \%$ of the total sampled population, while 43.8\% were Christians. The Muslims constituted the majority of the study participants.

Figure 2 shows that $9 \%$ of the sampled population had no formal education, $8 \%$ had only primary education, $50 \%$ had secondary school education and 33\% were graduates of tertiary institutions. This implies that most of the participants had only secondary school education.

Table 1: Demographic Variables.

\begin{tabular}{|c|c|c|c|c|c|}
\hline \multicolumn{2}{|l|}{ Gender } & \multirow{2}{*}{$\begin{array}{l}\text { Frequency } \\
132\end{array}$} & \multirow{2}{*}{$\begin{array}{l}\text { Percent } \\
38.8\end{array}$} & \multirow{2}{*}{$\begin{array}{l}\text { Valid Percent } \\
38.8\end{array}$} & \multirow{2}{*}{$\begin{array}{l}\begin{array}{l}\text { Cumulative (\%) } \\
\text { Percent }\end{array} \\
38.8 \\
\end{array}$} \\
\hline & Female & & & & \\
\hline \multirow[t]{2}{*}{ Valid } & Male & 208 & 61.2 & 61.2 & 100.0 \\
\hline & Total & 340 & 100.0 & 100.0 & \\
\hline \multirow[t]{3}{*}{ Age } & & Frequency & Percent & Valid Percent & $\begin{array}{l}\text { Cumulative (\%) } \\
\text { Percent }\end{array}$ \\
\hline & $11-15$ & 40 & 11.8 & 11.8 & 11.8 \\
\hline & $16-20$ & 145 & 42.6 & 42.6 & 54.4 \\
\hline \multirow{3}{*}{ Valid } & $21-25$ & 117 & 34.4 & 34.4 & 88.8 \\
\hline & $26-30$ & 38 & 11.2 & 11.2 & 100.0 \\
\hline & Total & 340 & 100.0 & 100.0 & \\
\hline \multicolumn{2}{|c|}{ Marital Status } & Frequency & Percent & Valid Percent & $\begin{array}{l}\text { Cumulative }(\%) \\
\text { Percent }\end{array}$ \\
\hline
\end{tabular}




\begin{tabular}{|c|c|c|c|c|c|}
\hline & Single & 252 & 74.1 & 74.1 & 74.1 \\
\hline \multirow[t]{3}{*}{ Valid } & Married & 74 & 21.8 & 21.8 & 95.9 \\
\hline & Others & 14 & 4.1 & 4.1 & 100.0 \\
\hline & Total & 340 & 100.0 & 100.0 & \\
\hline \multicolumn{2}{|c|}{ Ethnicity } & Frequency & Percent & Valid Percent & $\begin{array}{l}\text { Cumulative }(\%) \\
\text { Percent }\end{array}$ \\
\hline \multirow{4}{*}{ Valid } & Yoruba & 166 & 48.8 & 48.8 & 48.8 \\
\hline & Hausa & 13 & 3.8 & 3.8 & 52.6 \\
\hline & Igbo & 161 & 47.4 & 47.4 & 100.0 \\
\hline & Total & 340 & 100.0 & 100.0 & \\
\hline \multicolumn{2}{|c|}{ Family type } & Frequency & Percent & Valid Percent & $\begin{array}{l}\text { Cumulative }(\%) \\
\text { Percent }\end{array}$ \\
\hline \multicolumn{2}{|c|}{ Monogamous } & 98 & 28.82 & 28.82 & 28.82 \\
\hline \multicolumn{2}{|c|}{ Polygamous } & 196 & 57.65 & 57.65 & 86.47 \\
\hline \multicolumn{2}{|c|}{ Extended } & 46 & 13.53 & 13.53 & 100.0 \\
\hline \multicolumn{2}{|l|}{ Total } & 340 & 100.0 & 100.0 & \\
\hline
\end{tabular}

Source: Field survey 2017

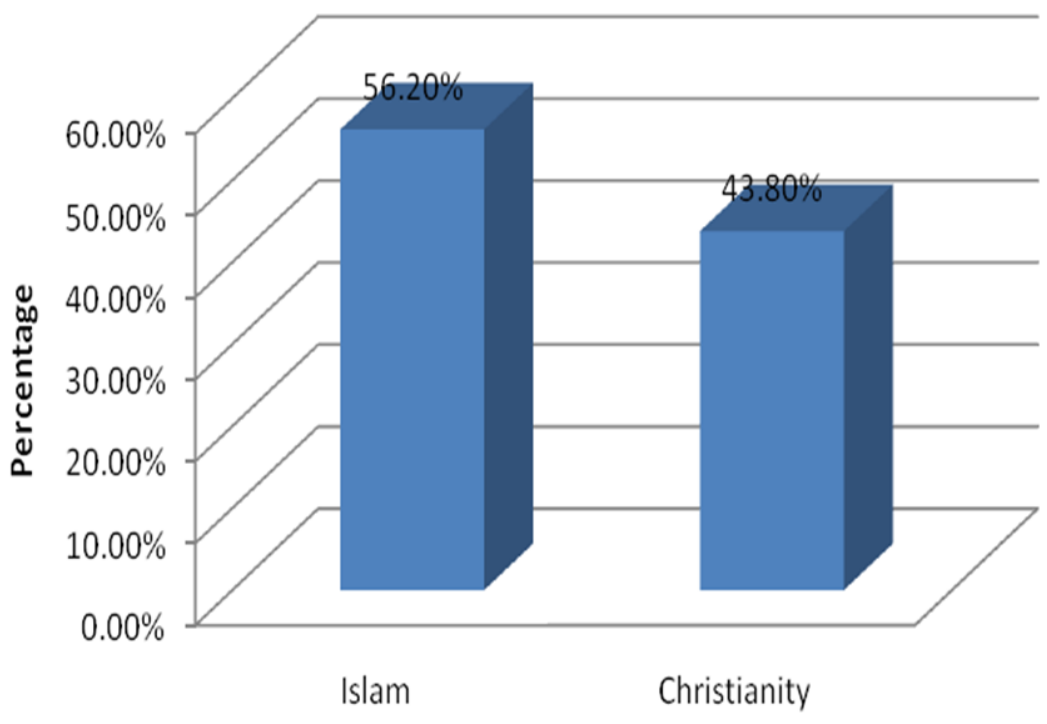

Respondents Religion

Figure 1: Bar chart showing Respondents Religious Affiliation. 


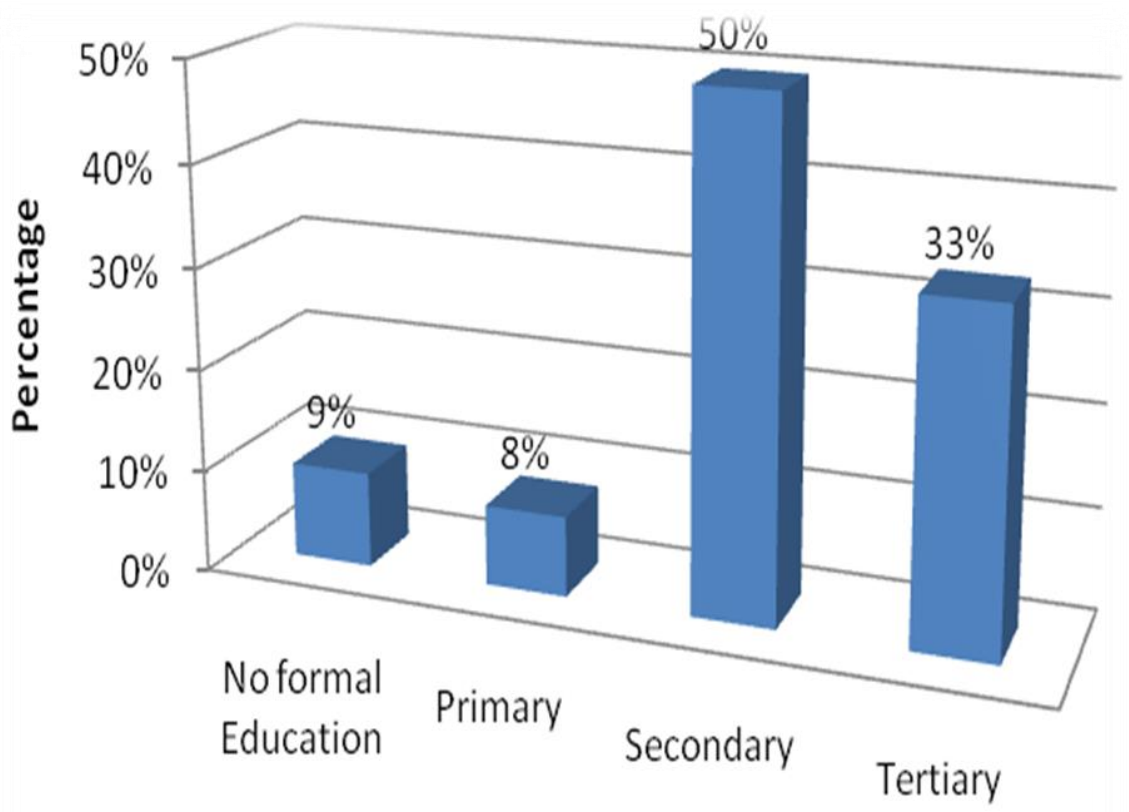

\section{Level of Education}

Figure 2: Bar chart showing the Level of Education of the Respondents.

Table 2: Knowledge of substance abuse among the youths.

\begin{tabular}{|c|c|c|c|c|c|}
\hline Constructs & $\begin{array}{l}\text { Strongly } \\
\text { Agreed }\end{array}$ & Agreed & Neutral & Disagree & $\begin{array}{l}\text { Strongly } \\
\text { Disagree }\end{array}$ \\
\hline $\begin{array}{l}\text { I have heard of the term drug abuse } \\
\text { substance abuse }\end{array}$ & $291(80.50 \%)$ & $43(17.60 \%)$ & $6(1.90 \%)$ & $0(0.00 \%)$ & $0(0.00 \%)$ \\
\hline $\begin{array}{l}\text { Am aware that the use of } \\
\text { Tobacco/cigarette is a type of drug } \\
\text { abuse among youth }\end{array}$ & $129(39.80 \%)$ & $198(54.70 \%)$ & $2(0.90 \%)$ & $10(3.70 \%)$ & $1(0.90 \%)$ \\
\hline $\begin{array}{l}\text { The use of un-prescribed drug is a form } \\
\text { of drug abuse }\end{array}$ & $149(40.70 \%)$ & $137(37.00 \%)$ & $22(8.30 \%)$ & $33(11.20 \%)$ & $1(2.80 \%)$ \\
\hline $\begin{array}{l}\text { Indiscriminate use of drug constitutes } \\
\text { drug abuse among youth }\end{array}$ & $157(42.60 \%)$ & $146(39.80 \%)$ & $29(10.20 \%)$ & $0(2.80 \%)$ & $8(4.60 \%)$ \\
\hline $\begin{array}{l}\text { When people smoke cigarette and "puff } \\
\text { it into the air especially in a crowded } \\
\text { place, they constitute drug/substance } \\
\text { abuse }\end{array}$ & $0(0.00 \%)$ & $57(17.40 \%)$ & $36(13.00 \%)$ & $128(36.10 \%)$ & $119(33.50 \%)$ \\
\hline $\begin{array}{l}\text { The use of volume } 3 \text { by students as a } \\
\text { means of sleeping properly constitute } \\
\text { drug/substance abuse } \\
\text { Sniffing cocaine and inhaling the } \\
\text { powder is a form of drug/substance }\end{array}$ & $169(48.1 \%)$ & $149(42.6 \%)$ & $0(0 \%)$ & $11(2.8 \%)$ & $11(6.5 \%)$ \\
\hline $\begin{array}{l}\text { abuse } \\
\text { I have knowledge of drug/substance }\end{array}$ & $187(52.8 \%)$ & $112(33.3 \%)$ & $0(0 \%)$ & $7(1.9 \%)$ & $34(12 \%)$ \\
\hline abuse because my friends have smoked & $119(35.1 \%)$ & $175(49.1 \%)$ & $3.7(0.9 \%)$ & $7(1.9 \%)$ & $35(13 \%)$ \\
\hline
\end{tabular}


cigarette indiscriminately

Smoking India hemp is very rampant among my school mates hence, my knowledge of drug abuse $180(49.1 \%) \quad 152(41.7 \%) \quad 0(0 \%) \quad 0(3.7 \%)$ $8(5.5 \%)$

The use of Narcotic analgesics (opium, morphine, codeine, and heroin) is very rampant among youth.

\begin{tabular}{lllll}
$187(52.8 \%)$ & $112(33.3 \%)$ & $0(0 \%)$ & $7(1.9 \%)$ & $34(12 \%)$ \\
\hline $44.15 \%$ & $36.65 \%$ & $3.52 \%$ & $6.60 \%$ & $9.08 \%$
\end{tabular}

Field survey, 2017

Table 3: Chi Square showing the youths' knowledge of substance abuse

\begin{tabular}{llll}
\hline & Value & df & Asymp. Sig. (2-sided) \\
\hline Pearson Chi-Square & $1595.645^{\mathrm{a}}$ & 621 & 0.000 \\
Likelihood Ratio & 994.630 & 621 & 0.000 \\
Linear-by-Linear Association & 297.930 & 1 & 0.000 \\
N of Valid Cases & 340 & & \\
\hline
\end{tabular}

\begin{abstract}
a. 668 cells $(99.4 \%)$ have expected count less than 5. The minimum expected count is .01.Inference
Since the $\mathrm{P}$ value of the Pearson is 0.000 , which is less than the benchmark of 0.05 , the null hypothesis is rejected and the alternate hypothesis is accepted; that is there is a statistically significant difference in the knowledge of substance abuse among youths in Alimosho Local government area of Lagos State. The findings in Tables 2 and 3 put together suggest that the youths may have adequate/proper knowledge about drug/substance abuse.
\end{abstract}

Table 4: The knowledge of substance abuse and the abuse of drug/substance among the youths.

\begin{tabular}{|c|c|c|c|c|c|}
\hline Constructs & $\begin{array}{l}\text { Strongly } \\
\text { Agreed }\end{array}$ & Agreed & Neutral & Disagree & $\begin{array}{l}\text { Strongly } \\
\text { Disagree }\end{array}$ \\
\hline $\begin{array}{l}\text { Youth abuse drug/substance to make } \\
\text { them feel happy and high }\end{array}$ & $38.70 \%$ & $44.20 \%$ & $10.20 \%$ & $6.00 \%$ & $0.90 \%$ \\
\hline $\begin{array}{l}\text { I take only one or two sticks of tobacco } \\
\text { daily to minimize the effect }\end{array}$ & $24.80 \%$ & $15.90 \%$ & $13.90 \%$ & $3.70 \%$ & $41.70 \%$ \\
\hline $\begin{array}{l}\text { I am aware that substance abuse is } \\
\text { harmful, but I am indifferent to the use } \\
\text { of un-prescribed drugs }\end{array}$ & $16.70 \%$ & $49.10 \%$ & $28.70 \%$ & $3.60 \%$ & $1.90 \%$ \\
\hline $\begin{array}{l}\text { I engage in substance/drug abuse to } \\
\text { boost my confidence especially during } \\
\text { party }\end{array}$ & $38.90 \%$ & $34.10 \%$ & $16.20 \%$ & $10.10 \%$ & $0.70 \%$ \\
\hline $\begin{array}{l}\text { I am thrilled when people smoke } \\
\text { cigarette and "puff it into the air } \\
\text { especially in a party; they do so to } \\
\text { signal their arrival }\end{array}$ & $40.70 \%$ & $23.50 \%$ & $7.40 \%$ & $5.60 \%$ & $22.80 \%$ \\
\hline $\begin{array}{l}\text { The use of Narcotic analgesics (opium, } \\
\text { morphine, codeine, and heroin) is very } \\
\text { rampant among youth. }\end{array}$ & $32.40 \%$ & $40.70 \%$ & $9.30 \%$ & $10.20 \%$ & $7.40 \%$ \\
\hline $\begin{array}{l}\text { Sniffing cocaine and inhaling the } \\
\text { powder provide strength, confidence and }\end{array}$ & $53.70 \%$ & $26.10 \%$ & $6.50 \%$ & $13.70 \%$ & $0 \%$ \\
\hline
\end{tabular}


sense of belonging to the gang

I abuse drugs because of pressure from my friends even though I know it is harmful $64.80 \%$ $23.20 \%$ $1 \%$ $1.09 \%$ $10 \%$

Smoking India hemp is very rampant among my school mates and almost always during break and after school hours $45.40 \%$ $28.10 \%$ $4.60 \%$ $21.90 \% \quad 0 \%$

\begin{tabular}{llllll}
\hline $\begin{array}{l}\text { I engage in taking cocaine only once in a } \\
\text { month to make me feel relaxed and high }\end{array}$ & $38.40 \%$ & $37.10 \%$ & $9.20 \%$ & $15.10 \%$ & $2.20 \%$ \\
\hline Average & $37.45 \%$ & $32.21 \%$ & $10.68 \%$ & $9.18 \%$ & $7.66 \%$ \\
\hline
\end{tabular}

Source, Field Survey, 2017.

Table 5: Relationship between the Youths' Knowledge of Substance Abuse and the Abuse of Substance.

\begin{tabular}{llll}
\hline & Value & df & Asymp. Sig. (2-sided) \\
\hline Pearson Chi-Square & $1567.353^{\mathrm{a}}$ & 702 & 0.000 \\
Likelihood Ratio & 894.700 & 702 & 0.000 \\
Linear-by-Linear Association & 251.239 & 1 & 0.000 \\
N of Valid Cases & 340 & & \\
\hline
\end{tabular}

a. 752 cells $(99.5 \%)$ have expected count less than 5 . The minimum expected count is .01 . Inference

Since the $\mathrm{P}$ value of the Pearson is 0.000 , which is less than the traditional benchmark of 0.05 , we reject the hypothesis and conclude that there is statistically significant association between knowledge of substance abuse and the abuse of drug among the youths in Alimosho Local Government Area of Lagos State. From the outcome of tables 4 and 5, it can be inferred that the apparent knowledge of drug abuse appears not to deter the youths from the use of drugs.

Table 6: Attitude of youths toward substance abuse.

\begin{tabular}{lccccc}
\hline Constructs & $\begin{array}{l}\text { Strongly } \\
\text { Agreed }\end{array}$ & Agreed & Neutral & Disagree & $\begin{array}{l}\text { Strongly } \\
\text { Disagree }\end{array}$ \\
\hline $\begin{array}{l}\text { Youth abuse drug/substance to make } \\
\text { them feel happy and high }\end{array}$ & $38.70 \%$ & $44.20 \%$ & $10.20 \%$ & $6.00 \%$ & $0.90 \%$ \\
\hline $\begin{array}{l}\text { I take only one or two sticks of tobacco } \\
\text { daily to minimize the effect }\end{array}$ & $24.80 \%$ & $15.90 \%$ & $13.90 \%$ & $3.70 \%$ & $41.70 \%$ \\
\hline $\begin{array}{l}\text { I am aware that substance abuse is } \\
\text { harmful, but I am indifferent to the use } \\
\text { of un-prescribed drugs }\end{array}$ & $16.70 \%$ & $49.10 \%$ & $28.70 \%$ & $3.60 \%$ & $1.90 \%$ \\
\hline $\begin{array}{l}\text { I engage in substance/drug abuse to } \\
\text { boost my confidence especially during } \\
\text { party }\end{array}$ & $38.90 \%$ & $34.10 \%$ & $16.20 \%$ & $10.10 \%$ & $0.70 \%$ \\
\hline
\end{tabular}


I am thrilled when people smoke cigarette and "puff it into the air especially in a party; they do so to signal their arrival $40.70 \%$ $23.50 \%$ $7.40 \%$ $5.60 \%$ $22.80 \%$

The use of Narcotic analgesics (opium, morphine, codeine, and heroin) is very rampant among youth.

$32.40 \%$

$40.70 \%$

$9.30 \%$

$10.20 \%$

$7.40 \%$

Sniffing cocaine and inhaling the powder provide strength, confidence and sense of belonging to the gang I abuse drugs because of pressure from my friends even though I know it is harmful $53.70 \%$ $26.10 \%$ $6.50 \%$ $13.70 \%$ $0 \%$ Smoking India hemp is very rampant among my school mates and almost always during break and after school hours $64.80 \%$ $23.20 \%$ $1 \%$ $1.09 \%$ $10 \%$

I engage in taking cocaine only once in

a month to make me feel relaxed and

\begin{tabular}{llllll} 
high & $38.40 \%$ & $37.10 \%$ & $9.20 \%$ & $15.10 \%$ & $2.20 \%$ \\
\hline Average & $37.45 \%$ & $32.21 \%$ & $10.68 \%$ & $9.18 \%$ & $7.66 \%$ \\
\hline
\end{tabular}

Source, Field Survey, 2017.

$\begin{array}{lllll}45.40 \% & 28.10 \% & 4.60 \% & 21.90 \% & 0 \%\end{array}$

Table 7: Chi-Square test result showing the Attitude of Youths to Substance Abuse

\begin{tabular}{llll}
\hline & Value & df & Asymp. Sig. (2-sided) \\
\hline Pearson Chi-Square & $809.339^{\text {a }}$ & 600 & 0.000 \\
Likelihood Ratio & 592.046 & 600 & 0.584 \\
Linear-by-Linear Association & 15.539 & 1 & 0.000 \\
N of Valid Cases & 340 & & \\
\hline a. 650 cells (100.0\%) have expected count less than 5. The minimum expected count is .01. \\
Inference \\
Since the P value of the Pearson is 0.000 which is less than the traditional benchmark of 0.05 , the hypothesis would therefore \\
be rejected and hence conclude that there is statistically significant association between attitude of youths to substance abuse \\
Put together, Tables 6 and seven suggests that the youths have an attitude that is supportive of substance abuse.
\end{tabular}

\section{DISCUSSION}

Substance use form parts of risk behaviours in which adolescents tend to engage themselves. In this study, most of the participants were single, there were more males participated than females and majority of participants were between 16-20 years of age with $50 \%$ of them having secondary school education (Table 1). These demographic variables are important because youths with these characteristics are said to be at risk of substance abuse as reported in previous studies carried. (Gudaji and Habib, 2015; Adeyemo et al., 2016). Youths in this age group are always curious about how substances will affect their behaviour or thinking, as a result they get involved in substance use which always leads to abuse. This stance was supported by Didarloo and Pourali (2016) where they also pointed out that curiosity is one of the individuals' factors that lead to substance abuse the most in a study they carried out in Kenya on university students. Usually, the first experience in drug 
abuse produces a state of arousal such as happiness and pleasure which in turn motivate youths to continue the act. Very importantly, the fact that this study revealed that more than half of the study participants were from polygamous homes, also suggests that they may have lacked proper parental love and care which is common in polygamous homes and are also predisposing factors to substance use; this usually make the youths to take solace in substance use for succor. This assertion is also supported by the finding of Akinnuoye et al. (2014) in a study they carried out in Ibadan among secondary school students where it was also confirmed that students from polygamous homes were more susceptible to substance abuse.

The first hypothesis in this study examined the knowledge of the youths on substance abuse and the result revealed that the youths may have some adequate knowledge on substance abuse as shown by the percentages in Table 2 and the $\mathrm{p}$ value $=$ $0.000<0.050$ in Table 3. In the same vein, the second hypothesis tested the relationship between knowledge of substance abuse among the youths and the use of substance. The result also revealed that there is a significant relationship between the knowledge of substance abuse and the use of substance. This relationship appears strong as indicated by the percentages in Table 4 and p-value of $<0.05$ in Table 5. Put together, one can infer that the youths in this study appear to have adequate knowledge of substance abuse. This is an interesting and encouraging finding since knowledge is expected to empower the youths in rationally overcoming substance use or abuse. On the contrary, the apparent knowledge of the youths did not prevent their disposition for abuse of substance as shown in Tables 4 and 5. One would have expected that if really the youths were knowledgeable and had the necessary facts about substance abuse, they would have strongly avoided any form of support for the use of substance but that was not the case. It has been reported in previous studies that drug abuse is affected by knowledge and attitude toward drugs. One of such studies is the study of Geramian et al (2014) in Iran, where it was reported that knowledge of substance abuse among youths was able to correct the attitude of youths toward illegal drugs and strengthening their confidence in this regard. They further indicated that to change behaviour, at first knowledge and attitude toward that particular behavior should be corrected. Since the finding in this study indicate apparent knowledge, and the youths still appear to be indifferent to illicit drug use, it shows that in reality, they may not have acquired the necessary knowledge with convincing facts to have a change in behaviour. Therefore, more facts concerning substance abuse need to be given to them and the possible effect of indulging in such behaviour needs to be explicitly explained to them, as well as a more intensive evaluation put in place in order for them to have a change in behaviour. This can be achieved through public health education of the youths by interacting with them and educating them properly on the health consequences of substance abuse so that they can achieve optimum health.

The third hypothesis which tested the attitude of the youths toward substance abuse showed that the youths were positively disposed to substance abuse (tables 6 and 7). The result actually infers that the youths were favourably disposed to substance abuse despite their apparent knowledge of the risks of substance abuse. As discussed above, the apparent knowledge of the youths did not change their belief in substance use. In this study, although the implications of using illicit substances appeared to be widely recognized, the attitude of the participants did not reflect any knowledge on why substance use should 
be avoided. Previous studies revealed that attitudes are influenced by a variety of factors, including past experiences, knowledge of the problem and population, as well as one's general beliefs. Positive attitudes are displayed by behaviors that are accepting rather than rejecting. The reasons for increase in substance abuse despite apparent knowledge may also be attributed to idleness especially since most youths are jobless; incessant strike actions by the academic and non-academic staff of universities which increase idleness among the youths as well as social and peer pressure. Parental influence may also be a factor responsible for substance abuse; some parents also send their children to purchase drugs and take such drugs in the presence of their children.

This finding supported previous study conducted by Danjuma et al. (2015) in the Federal polytechnic, Bida, where they reported that five in every ten participants in their study opined that most of the nonconventional substance users are aware of the dangers associated with the abuse of substances, yet, nothing deterred them from substance abuse. This finding is also corroborated by the finding of a similar study carried out in Ethiopia by Liranso et al. (2017) on substance abuse among youths in Addis Ababa where it was reported that Majority of participants had adequate knowledge about harmful effects of addictive substances, yet they were involved in taking illicit drugs. They further pointed out that the youths had limited information regarding treatment and intervention options. This highlights the need for spreading more awareness about treatment of substance abuse via awareness creations, lectures, media and campaign at larger levels. In the same vein, the situation of substance abuse among the youths in this study is disturbing and warrants the need for urgent action by all stakeholders (parents, teachers, government) to reduce the menace of substance abuse.

\section{Conclusion}

In conclusion, based on the findings in this study, the youths in Alimosho Local Government area of Lagos State were apparently knowledgeable about substance abuse but their attitude to substance use was apparently not influenced by their knowledge. This negative attitude is a cause for concern since the youths are the future of the nation. By this attitude one may infer that their knowledge may be general; therefore, there is the need for proffered solution through appropriate counseling and health education of the youths specifically emphasizing the health risks of substance abuse and its consequences. This is very vital because they stand higher risks usually associated with substance abuse and these include developing alcohol-related disorders, including liver cirrhosis, and a greater propensity to experience toxic effects of cocaine that may lead to earlier onset or greater risk for health problems, particularly cardiovascular disease and HIV/AIDS. Subsequent study will therefore embark on health education of youths on the health effects of substance abuse and on how to prevent or come out of substance use. Emphasis will be on factors that can guide the planning, designing and implementing of prevention programmes that focus on raising awareness about the harms of substance use. Thus, multifactorial prevention programmes that address social norms, gender role and image, and incorporate drug policy, religion, family and school may be more effective and may have better protective outcomes.

It is therefore recommended that Health education intervention should be vehemently carried out among youths, stressing the health implications of substance abuse and teaching them how to come off 
substance abuse through psychotherapy. A more comprehensive study should be carried out in order to formulate policy or guideline for a health education programme to address the growing problem of substance abuse in young population. The government should take a vibrant step to implement and ensure that existing policies on substance abuse are carried out. Legislation guiding sales of drugs should be enforced, the public should be educated and the sale of drugs monitored. Social media should also control the way they portray some drugs (alcohol, cigarette) to entice the youths since youths are easily influenced by what they see. Also, parents, educators and all stakeholders must come together and be in the forefront to fight the menace of substance abuse in our society.

\section{COMPETING INTERESTS}

The authors declare that there are no competing interests.

\section{AUTHORS' CONTRIBUTIONS}

GOA: Study conception and Design, Drafting of manuscript and Critical revision. Both authors jointly interpreted data. MFO-TS: Acquisition of data, Analysis, Both authors jointly interpreted data.

\section{ACKNOWLEDGEMENTS}

The Authors wish to acknowledge the Health Research and Ethics Committee (HREC) of the Federal Neuropsychiatry Hospital Yaba, Lagos and the Chairman of Alimosho Local Government Area of Lagos State for their support which made it possible to carry out this study.

\section{REFERENCES}

Adeyemo FO, Ohaeri B, Okpala PU, Oghale O. 2016. Prevalence of Drug Abuse Amongst University Students in Benin City, Nigeria. Public Health
Research, 6(2): 31-3.

Doi:10.5923/j.phr.20160602.01.

Akinnuoye MA, Akinnuoye OF, Mokhtar J. 2014. Causative Factors and Problems Associated with the Use and Abuse of Psychoactive Substances among Students of Secondary Schools in Lagelu Local Government of Oyo State, Nigeria. $\quad$ From www.iiste.org/journals/index.php/RHSS/ article/download/18465/19071. Accessed January10, 2016.

American Psychiatric Association. 2013. Diagnostic and Statistical Manual of Mental Disorders (5th edn). American Psychiatric Publishing: Arlington, VA.

Cherpitel CJ, Bond J, Ye YU. 2003. A cross national meta-analysis of alcohol and injury: data from the emergency room collaborative alcohol analysis project(ER CAAP). Society for the study of addiction to alcohol and other drugs. Addiction, 98: 1277-1286. DOI: 10.1046/j.1360- 0443.2003.00459.x

Danjuma A, Taiwo AI, Omoniyi SO, Balarabe SA, Kolo S, Sarah SL, Nassa YG. 2015. Nonconventional Use of Substances among Youth in Nigeria: Viewpoints of Students in a Nigerian Tertiary Institution. $\quad J$ Nurs Care 4: 311. Doi:10.4172/2167-1168.1000311.

Didarloo A, Pourali R. 2016. University Students' Views Regarding Reasons for Drug Abuse Among Youths. Int J High Risk Behav Addict., 5(1): e24778. Doi: 10.5812/ijhrba.24778.

Fareo DO. 2012. Drug Abuse among Nigerian Adolescents Strategies for Counselling. The Journal of International Social Research., 5(20):1-7.

Fatoye FO, Morakinyo O. 2002. Substance use among secondary school students in rural and urban communities in South Western Nigeria. East African Medical Journal, 79(6): 299-305. 
Doi.org/10.4314/eamj.v79i6.8849

Gashaw A, Teshita A, Getachew T. 2016.

Environmental tobacco smoke exposure and its health impacts: a review. Int. J. Biol. Chem. Sci., 10(3): 1370-1381. http://dx.doi.org/10.4314/ijbcs.v10i3.36

Geramian N, Gharaat L, Taheri SA, Mohebpour F, Nahvizadeh M, Farajzadegan Z, Heidari K. 2014. Development of a questionnaire to assess drug abuse among high school students of Isfahan Province, Iran: an action research. Int J Prev Med., 5(2): S146S153.

Global Burden of Disease Study. 2013. Mortality and Causes of Death, Global, Regional, and National Age-Sex Specific All-Cause and Cause-Specific Mortality for 240 Causes of Death, 1990-2013: A Systematic Analysis for the Global Burden of Disease Study 2013. Lancet, 385: 117-171. Doi: 10.1016/S01406736(14)61682-2.

Gudaji MI, Habib ZG. 2015. SocioDemographic factors associated with psychoactive substance use among commercial motorcycle operators in Kano, Nigeria. Open Journal of Psychiatry, 6: 76-85. Doi: 10.4236/ojpsych.2016.61009

Lagos State Bureau of Statistics. 2013. Abstracts of Local Government Statistics. From http://lagosbudget.org/abstract-of-localgovernment-statistics Accessed January $10,2016$.

Lagos State Government Digest of Statistics. 2013. From

http://mepb.lagosstate.gov.ng/wpcontent/uploads/sites/29/2017/01/2013-

Digest-ofStatistics.pdf.

Accessed

December 2, 2016.

Lagos State Government Ministry of Health (LMoH). 2017. Drug Abuse Control Strategy.

From http://health.lagosstate.gov.ng/drug-

abuse-control-strategy/ Accessed

October 15, 2017.

Liranso GS, Eliyas KA, Israel FF. 2017. Drug and Substance Abuse Knowledge and Attitudes among Youth in Addis Ababa Ethiopia. J Subst Abuse Alcohol, 5(2): 1056.

Omalase CO, Afolabi OT, Omalase BO, Ihemedu CO. 2011. Drink-driving among commercial drivers in a Nigerian community. Middle East Journal of Psychiatry and Alzheimers, 2(2): 15-18.

DOI 10.5742/MEJPA.2011.22051.

Omorogiuwa A, Okolo O. 2015. Effect of acute hyperglycemia on clotting time and relative plasmaviscosity (RPV) during menstruation. International Journal of Biological and Chemical Sciences, 9(6): 2918-2923.

http://dx.doi.org/10.4314/ijbcs.v9i6.30

Oshikoya KA, Alli A. 2006.Perception of drug abuse amongst Nigerian undergraduates. World Journal of Medical Sciences, 1(2): 133-139.

Oshodi OY, Onajole AT, Aina OF. 2010. Substance use among secondary school students in an urban setting in Nigeria: prevalence and associated factors. Afr $J$ Psychiatry, 13: 52-57.

Sheldon BH, Quin JD. 2005. Diabetes and illicit drug use. Practical Diabetes Int, 22(6): 222-224.

Suleiman GT, Adeyemi SO, Adeponle AB. 2006. An overview of psychoactive substance use and misuse in northern Nigeria. Nigerian Journal of Psychiatry, 4(1): 8-14.

United Nations Office on Drugs and Crime (UNODC). 2012. World Drug Report 2012. From https://www.unodc.org/unodc/en/dataand-analysis/WDR-2012.html Accessed August 2, 2017. 
Vue MH, Setter SM. 2011. Drug-Induced Glucose Alterations Part 1: DrugInduced Hypoglycemia. Diabetes Spectrum, $\quad \mathbf{2 4}(3)$ : $\quad 171-177$. https://doi.org/10.2337/diaspect.24.3.171 Welcome MO, Pereverzev VA. 2010. Limit of blood alcohol concentration: A major problem to solve in Nigeria. European Psychiatry,

25: 544. doi.org/10.1016/S0924- 9338(10)705393.

World Drug Report. 2012. United Nations Office on Drugs and Crime. From https://www.unodc.org/documents/dataand analysis/WDR2012/WDR_2012_web_s mall.pdf Accessed June 5, 2017.
World Health Organization. 2002. Prevention of psychoactive substance use. From www.who.int/mental_health/evidence/en /prevention_intro.pdf. Accessed January 30, 2017. World Health Organization. 2012. Management of substance abuse. From http://www.who.int/substance_abuse/pub lications/tax_book/en/ Accessed March 4, 2017.

World Health Organisation. 2017. Global developments in alcohol policies: Progress in implementation of the WHO global strategy to reduce the harmful use of alcohol since 2010. From http://www.who.int/substance_abuse/acti vities/fadab/event/en/ Retrieved June 10, 2017. 